\title{
FFPS news
}

\section{FFPS Council Members}

Bruce Coleman, Dr Chris Humphries and Richard Steele were newly elected to the FFPS Council in October 1987.

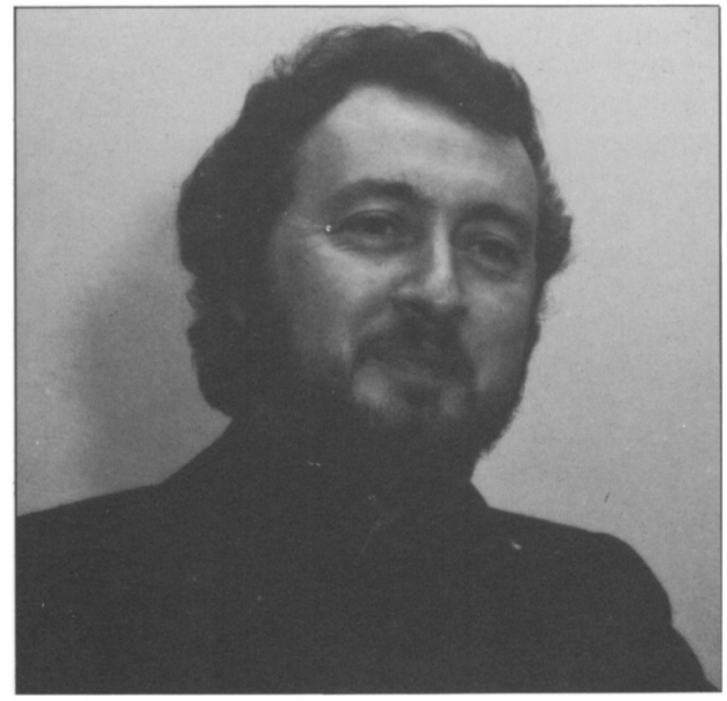

\section{Bruce Coleman}

For someone who is a reluctant committee person, Bruce Coleman has been Secretary of the Hertfordshire \& Middlesex Trust for Nature Conservation, Chairman of the Publicity \& Appeals Committee of ICBP (British Section), President of the British Association of Picture Libraries \& Agencies, and represents the FFPS on the Policy Committee of the Wildlife Photographer of the Year awards and is Chairman of its judging panel. He is also Chairman of FFPS's Publicity \& Fund Raising Advisory Group.

Twenty-eight years ago Bruce established his UK Photographic Agency and through it was soon presenting ideas and concepts to publishers, which over the years have initiated a host of books, guides, and part-works devoted to wildlife. Within a few years he also successfully established a New York subsidiary, but five years ago relinquished control to his Manager to allow more time for other ventures, including more time for conservation and wildlife watching. This means adding to his annual spring visits to northern Mallorca for raptors and wetland birds, the 130 winter trips to Islay for geese and more raptors, and the 'big trips' to the Indian Ocean, Middle East, Africa and the United States.

\section{Chris Humphries}

Dr Chris Humphries has served on the FFPS Council before, from 1982 to 1984, and for the past six years has been closely involved in the designing and monitoring of the Society's botanical projects, especially those producing trade documents on orchids, mahoganies and cacti. $\mathrm{He}$ is a member of the Flora Working Group, which was responsible for the appointment of the Society's first full-time botanical officer, and a member of the Editorial board of Oryx.

Born in Derbyshire, England, in 1947, his interest in biology started when he was 15 . He gained a BSc at Hull University in 1969 and a $\mathrm{PhD}$ from Reading University in 1973. It was not until 1972, when he was appointed to the British Museum (Natural History), that he says he became truly conservation conscious, and he feels that his first effective piece of conservation work was in getting Charlie Jarvis to write a report on cacti in trade in 1979.

His career at the British Museum progressed from being made head of the European Herbarium in 1974 to being put in charge of the Mesoamerican collections, with a special responsibility for managing research on flowering

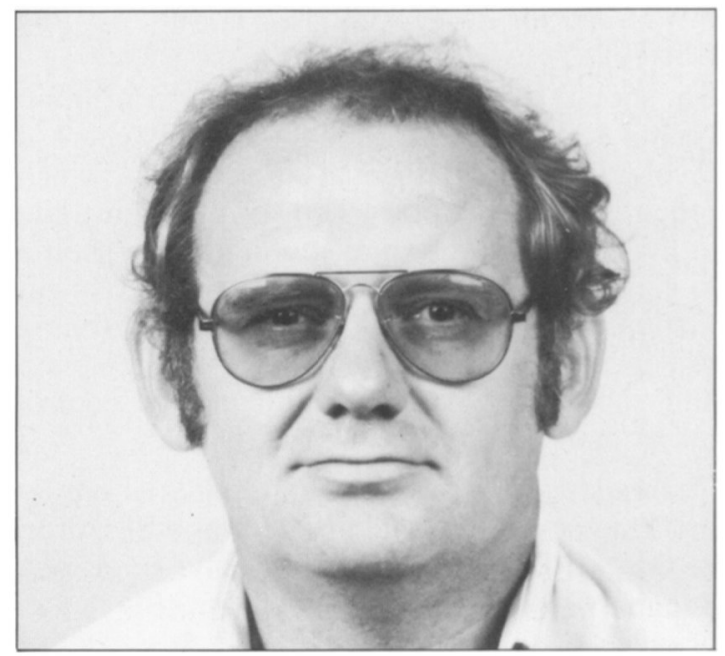

Oryx Vol 22 No 2, April 1988 


\section{FFPS news}

plants. Since 1976 he has specialized in quantitative systematics, particularly quantitative cladistics. He was a founder member of the Willi Hennig Society, creator of its journal Cladistics and now its editor, and a member of Council. He has an impressive list of publications, some of them resulting from invited lectures in various parts of the world, and he has field experience in Europe, north Africa, Australia, New Guinea, Costa Rica, Panama, and Mexico. He was honoured in 1980 by the Linnaean Society of London when it awarded him the bicentennary silver medal as Scientist of the Year.

\section{Dick Steele}

Dick Steele was born in Burma, where his father was in the Burma Civil Service, but he spent his boyhood in South Devon. In his school holidays he worked on a mixed farm, when he gained his life-long interest in the countryside, its activities and its plants and animals.

After National Service in the Royal Artillery he took degrees in forestry and botany at the University College of North Wales in Bangor. He was always keen to work overseas and in his application for the Colonial Forest Service asked to be posted to East Africa and, when asked why, said that he was fascinated by the variety and number of animals there. The Interview Board members must have been sympathetic and shortly afterwards he found himself on a ship bound for East Africa.

From 1951, he spent 11 very happy years in Tanganyika (now Tanzania) working on the silviculture and management of natural forests, and also plantations of Eucalyptus and North American pines that were being established. He travelled in East, Central and South Africa and his evenings and weekends were often spent with rifle, shotgun or fishing rod in hand. A particularly enjoyable posting in 1958 was to Ngorongoro to study the dependence of the Maasai on the forests there, and to recommend how their need for poles, firewood and grazing could be met without destroying the forests. For some months he and his wife camped and toured in many parts of the Crater Highlands and the Serengeti.

FFPS news
In 1962 he returned to Britain and was appointed Head of the Woodland Management Section at Monks Wood Experimental Station of the Nature Conservancy. The Station was then under construction and the staff was being built up. Over the next decade, he was involved in management, research and advisory work in woodland conservation throughout Britain, and internationally through the International Union of Forestry Research Organizations.

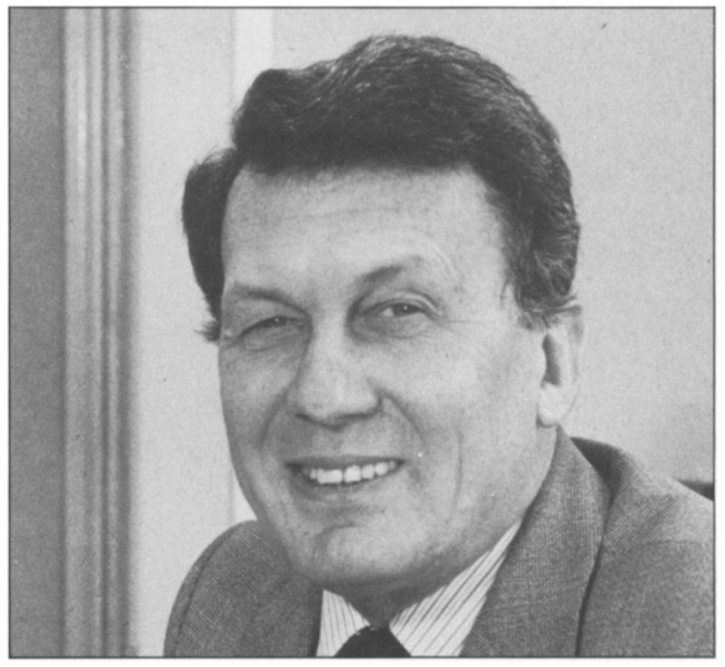

In 1973 he joined the Natural Environment Research Council as Head of the Terrestrial and Freshwater Life Sciences Division, and in 1978 he went to the Institute of Terrestrial Ecology (made up from the research stations of the former Nature Conservancy) as Head of the Division of Scientific Services. In 1980 he was appointed Director General of the Nature Conservancy Council.

He is a Fellow and past President of the Institute of Chartered Foresters and a Fellow of the Institute of Biology. Since 1984, he has been an elected Council Member for Western Europe of the International Union for Conservation of Nature. He is also a member of the Council of the National Trust.

Married with three children and two grandchildren, his interests still lie in the countryside, in gardening and in walking, especially on the west coast of Scotland where he spends his summer holidays. 


\section{FFPS news}

\section{Oryx $100 \%$ Fund grants}

At its meeting on 6 January 1988 the FFPS Council approved the following grants from the Oryx 100\% Fund.

$£ 500$ for a survey of the Ambohitralana Forest, the largest block of lowland forest remaining in Madagascar. The expedition members intend to study lemurs, small mammals, birds, reptiles and ferns, and to continue ethno-botanical work that they had begun on a previous expedition, with the objective of encouraging the establishment of a large lowland forest reserve.

$\mathbf{£ 5 0 0}$ for a study on the ecology, distribution and conservation of Liberian mongoose Liberiictis kuhni, a rare and poorly known species. The project includes live-trapping in the newly created Sapo National Park and along the Cestos and Cavallo Rivers. It is hoped that a captive breeding programme may be set up should this study indicate that this is practicable.

$£ 400$ for an ecological survey and human impact assessment of the caves of Guangxi, China. A range of cave sites will be surveyed in collaboration with the Karst Research Institute. Cave biology is a neglected subject in China and the recipient of the grant wishes to foster an interest in cave ecology among the Chinese by demonstrating the richness of the fauna. It is also his intention to provide guidelines for the conservation of bats and swiftlets.

$\mathbf{£ 3 0 0}$ for a study on the freshwater land turtles and tortoises in Bangladesh. Many of the species involved are exploited for food, but little is known about the impact this has on population sizes.

\section{FFPS Inc installs salamander tunnels}

Following the success of Britain's first toad tunnel, installed by FFPS in England in March 1987 (see Oryx, 21, 202), FFPS Inc. decided to follow suit and set up a similar project in Massachusetts, USA. After studying several New England sites, FFPS's Boston office decided to build two tunnels on Henry Street, Amherst, Massachusetts, and completed the tunnels in November 1987. 132
The site had already received much publicity, including extensive international coverage, due to the street having been closed off in recent years to allow the spotted salamanders Ambystoma maculatum to cross to their breeding ponds.

There are estimated to be approximately 400 salamanders in this local population. Spotted salamanders are not considered to be endangered or threatened, although this particular population would have been considerably reduced by very heavy traffic if conservation measures had not been taken. It is worth noting that salamander numbers have been declining throughout New England. Known reasons for this decline are habitat destruction, collecting and traffic fatalities, with an additional suspicion, as yet unsubstantiated, that acid rain is a detrimental factor.

Amherst is an excellent location for a pilot scheme: it has an ongoing salamander conservation project under the direction of devoted local naturalist Robert Winston; several conservation groups are active in the area and are willing participants in the project; and all municipal officials are very enthusiastic and helpful.

The project should be fascinating to conservationists for at least three major reasons. It is being conducted in the midst of human development, not at the usual isolated nature site, and because of this it offers an opportunity for cooperation between government, conservationists, local citizens and land owners. Secondly, it has drawn sympathetic public attention to the plight of reptiles and amphibians. Finally it highlights the problem of road deaths.

It has been estimtated that over one million wild animals are killed daily on roads in the United States. This factor can be said to be like the weather-everyone complains, but no one does anything about it. Amphibians and reptiles may suffer more than any other group because roads are often built across their ancient migratory routes. We suspect that damage to a local population is often insidious, particularly in the case of slow-moving turtles. Over a period of time, egg-bearing females are destroyed and the population declines through attrition.

Oryx Vol 22 No 2, April 1988 
It is the intention of the FFPS to ensure that safe crossing for all wildlife becomes an integral component of highway planning and design. Identification of animal crossing sites can be made easily during the planning stage, and the roads can be designed and built accordingly. Simultaneously, remedial steps can be taken to correct existing problems as is beginning to be done in Britain and the United States. This is by no means an easy task, but it must be undertaken.

The Amherst tunnels were built through a cooperative effort, with FFPS Inc. working in partnership with the Massachusetts Audubon Society and ACO Polymer Company Inc. Massachusetts Adubon provided much of the financial and technical support through its naturalist, Tom Tyning, and University of Massachusetts graduate student in herpetology, Scott Jackson. ACO Polymer donated both tunnels and paid for their shipping from Ohio.

Duane Pierson, Executive Director, FFPS Inc.

\section{FFPS flora projects}

Since his appointment at the end of March 1987, Mike Read, FFPS Botanical Conservation Officer, has been involved in a number of activities. They include preparing a report, Threatened Bromeliads in Trade, which was presented to the CITES conference in Ottawa in July. TRAFFIC West Germany has now taken up the issue. He has also been helping with the development of a CITES identification manual for plants.

Below he describes the background to a major project concerning wild-collected bulbs in Turkey. He carried out background research before setting out on a fact-finding visit to Turkey in October. Once there, discussions with botanists at Ankara and Istanbul Universities, Turkish conservationists, the Ministry of Agriculture, Forestry and Rural Affairs, major plant exporters, and villagers gave him the opportunity to assess the problems, consider solutions and promote ideas for improving the prospects of these plants. The publicity achieved so far has led to an opening of discussions with the Bulb Information Desk (the body representing the interests of the Dutch bulb trade in the UK) and attempts are being made to persuade all major chain-stores and garden centres to adopt a more responsible attitude. FFPS news

\section{Endangered bulbs-FFPS action}

The FFPS is pressing for strong controls on the increasing trade in wild-collected species of bulbous plants. Each year Turkey alone exports over $100,000,000$ bulbs, almost entirely obtained from wild populations.

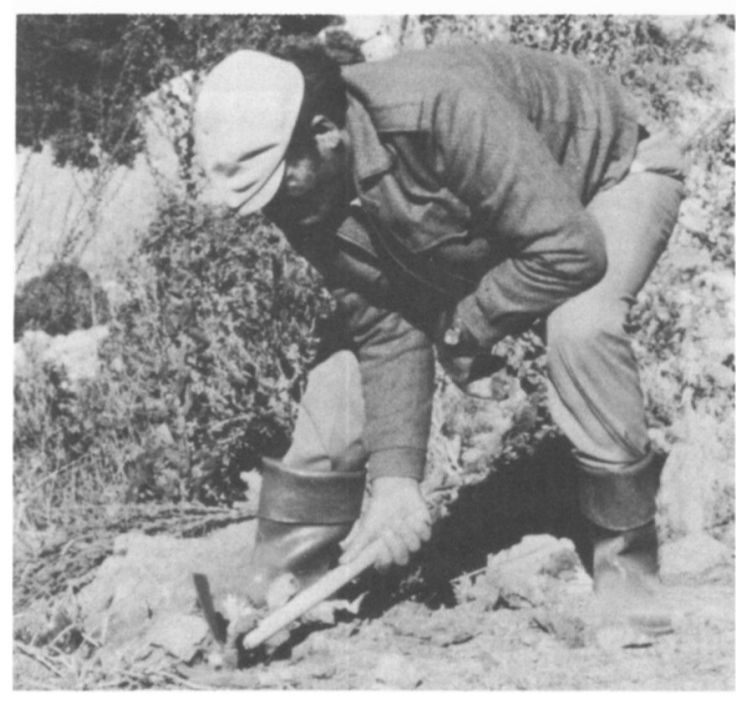

Turkish villager collecting bulbs of colchicum near Marmaris, SW Turkey (Mike Read).

The Anatolian Plateau, which occupies most of Turkey, is one of the richest areas in the world for bulbs. Indeed, many of the most familiar garden plants come from Anatolia, including snowdrops Galanthus spp., tulips Tulipa spp., and cyclamen Cyclamen spp. Lilies Lilium spp., and crocus Crocus spp., from the coastal regions combine to make Turkey a country of remarkable interest to both botanists and horticulturalists.

Bulbous plants are characterized by their ability to survive unfavourable seasons through the adaptation of part of the plant into a swollen storage organ. However, this very feature can also work to their disadvantage-making them easily transported.

The trade in bulbs from Turkey has a very long history. As long ago as the reign of Suleiman the Magnificent (1520-1566), tulips were exported to Austria. The extent of this trade has fluctuated over the years, but during the 1970 s 


\section{FFPS news}

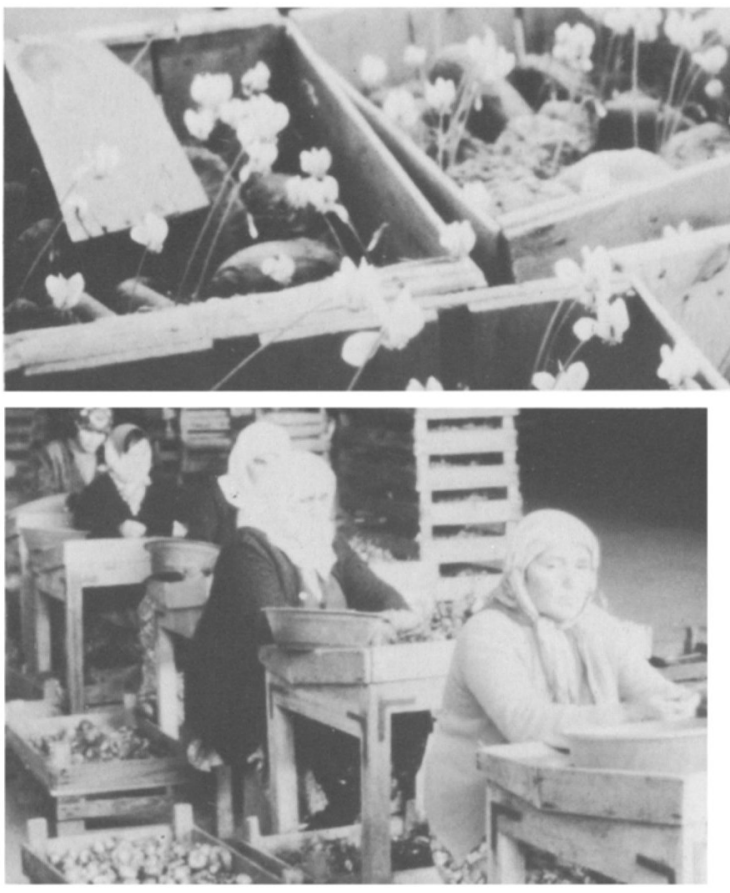

and 1980s it has been growing to enormous proportions. In 1986 alone exports topped 50,000 for at least 12 genera and several were in the millions (see Table). These plants are collected almost exclusively from the wild, usually while the plants are in flower, thus removing the possibility of their reproduction from seed. While there are some attempts at propagation in nurseries in Turkey, their overall contribution to reducing the number of plants collected from the wild is negligible. Turkish botanists are increasingly concerned by the current situation.

Table. Numbers of various genera of bulbs exported from Turkey in 1986

\begin{tabular}{lc}
\hline Iris spp. & 56,000 \\
Tulipa spp. & 97,500 \\
Arum spp. \& Dracunculus spp. & 191,000 \\
Scilla spp. & 200,000 \\
Calla spp. & 240,000 \\
Sternbergia spp. & 259,500 \\
Fritillaria spp. & 750,500 \\
& Crown Imperials', etc. \\
Cyclamen spp. & $2,408,500$ \\
Anemone blanda & $6,423,500$ \\
Leucojum spp. & $7,678,500$ \\
& 'SummerSnowflakes' \\
Eranthis spp. & $13,118,500$ \\
& 'WinterAconites' \\
Galanthus spp. & $38,635,500$ 'Snowdrops' \\
\hline
\end{tabular}

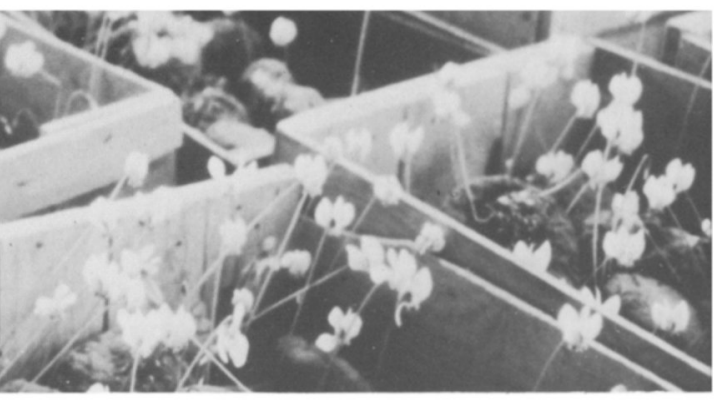

Boxes of Cyclamen hederifolium awaiting transport across Europe to Holland (Mike Read).

Preparing Gladiolus bulbs for export in a warehouse near Istanbul (Mike Read).

It is not only the rare and local species that are threatened, but also once-common species, subjected to several years of such intensive collection, are beginning to disappear. The Turkish endemic Galanthus elwesii, sold to gardeners around the world labelled simply as 'snowdrops', has suffered badly from over-collection in both the Mediterranean region (Taurus Mountains) and the Aegean region. The only whiteflowered sternbergia species, Sternbergia candida, was virtually wiped out by commercial exploitation within two years of its discovery in south-west Turkey.

Of the dozens of species threatened in this way, only cyclamens are covered by the Convention on International Trade in Endangered Species of Wild Fauna and Flora (CITES) and even they continue to be dug up and exported in alarming numbers. The EEC has established a quota of approximately $1,000,000$ for imports of cyclamen tubers from Turkey. However, altering trade routes and destinations, Turkey continues to export 2,500,000 annually. Among these have been found the rare endemic $C$. mirabile and $C$. trochopteranthum, both of which are banned from export by Turkish authorities. There are very few species awarded this level of protection in Turkey. All others are thus at the mercy of the international horticultural trade.

All of those species threatened by stripping from the wild can be artificially propagated. However, most bulbous plants take several years to reach a marketable size. Consequently, the availablilty of cheap local labour in the countries of origin provides all but the few responsible bulb suppliers with an all too convenient alternative.

Oryx Vol 22 No 2, April 1988 


\section{FFPS news}

Undoubtedly many wild populations of plants could withstand a regular level of 'cropping', carefully monitored and controlled. However, the information required to assess sustainable levels and appropriate methods of collection does not yet exist. The establishment of nurseries propagating native plants in countries such as Turkey could go a long way to solving these problems.

Mike Read, FFPS Botanical Conservation Officer.

\section{Guanacaste National Park}

In his address to the Society last October, Dr Dan Janzen of Philadelphia University, USA, gave an update on the project to plant a tropical forest in Costa Rica (see Oryx, 21, 135.).

A film about this ambitious project-Paradise Reclaimed - was shown on BBC 2 on 22 November. Viewers were told about a free booklet, produced by the Society in co-operation with the BBC Natural History Film Unit, which is still available from the FFPS office. (UK members please enclose a $13 \mathrm{p}$ stamped addressed envelope.) The booklet includes details of how to obtain a share in the future of Guanacaste National Park.

The FFPS Guanacaste Fund is still open and has so far raised about $£ 15,000$.

\section{FFPS recommendations adopted}

In 1986 John Burton led a three-man delegation to Kashmir to investigate the fur trade and to make recommendations on fur ranching. The delegation also included Don Gearing of Hudson's Bay and Annings and Newman Burberry, a mink farmer. They concluded that operations such as mink ranching would be very undesirable in Kashmir, particularly on ecological grounds.

We have recently heard from Dr M. K. Ranjitsinh, Joint Secretary for Wildlife in the Indian Ministry of Environment and Forests, that rather than activate ranches to potentially damaging effect, the Central Government will give financial support to the expansion of angora rabbit farms. The rabbits (which are sheared for their fur) have FFPS news an added advantage in that they provide meat for human consumption. The Government also intends to acquire the fur of protected species (such as snow leopard), which have been obtained legally in the past. The existence of these in Kashmir has been a serious problem for many years as new furs and skins can be falsely described as old to evade the law. When in Srinagar, John Burton saw the skins of snow leopards and many other protected species being offered for sale.

\section{FFPS support for mountain gorilla conservation in Uganda}

As part of its long-term support for gorilla conservation in Central Africa, the FFPS has contributed $£ 1800$ to the Impenetrable Forest Conservation Project for the construction of a guard's camp.

The Impenetrable, in south-east Uganda, is one of the most important forests in Africa. It has an extraordinarily rich fauna and flora and shelters approximately one-third of the world's mountain gorillas, the rest being in the nearby Virunga range on the Uganda-Zaire-Rwanda frontier. Whilst the situation improves in the Virunga, it remains grave in the Impenetrable. All the familiar threats are there: timber and bamboo exploitation, gold-mining, grazing of livestock and, above all, poaching. Over the past 18 months, a probable nine to twelve gorillas have been taken from a total population of $c$. 115, and that is suspected to be an underestimation.

The Game Department staff are determined, with the help of the Impenetrable Forest Conservation Project, to stop the poaching. The FFPS funds, drawn from the generous donations made to the Society by its Mountain Gorilla Project supporters, gives the guards the base they need to operate from.

\section{Partula tree snails}

One of the seven endemic Partula tree snails of the island of Moorea in French Polynesia in the South Pacific is probably now completely extinct. A survey in July 1987, by Dr Jim Murray, funded by the Species Survival Commission's Captive Breeding Group, found no living Partula species at all on Moorea. Dr Bryan Clarke, a 
geneticist at the University of Nottingham, who has been studying the snails for over 20 years, long ago predicted that the snails would become extinct in the wild by the end of 1987. The FFPS's Oryx $100 \%$ Fund gave $£ 650$ in 1981 to Dr Clarke to rescue five of the island's nine species and breed them in captivity.

On 16 April 1987 the FFPS also hosted a Partula Snail Workshop in London at the instigation of Sue Wells, of IUCN's Conservation Monitoring Centre, and Dr Ulysses Seal, Chairman of the Species Survival Commission's Captive Breeding Specialist Group. The workshop produced a detailed captive breeding programme to be implemented by 18 of the world's zoos and costing $£ 60,000$. The snails are already being bred in universities in Nottingham, Virginia and Perth, at the Jersey Wildlife Preservation Trust and at London Zoo, but funds are still sought to maintain the long-standing laboratory colonies, to mount a publicity campaign and to develop reserves and enclosures on Moorea for the future reintroduction of Partula. Six of the seven species are in captivity; although for one species there are only seven individuals.

Partula snails were exterminated in the wild by the predatory snail Euglandina rosea, introduced in an attempt to control the introduced giant African snail. It was introduced to Hawaii in 1955 and has contributed directly to the extinction of 22 of the known 46 endemic species of Achatinella. On Tahiti, too, E. rosea is spreading fast and may eventually exterminate the endemic Partula of that island.

Astonishingly, despite what has happened on Moorea, people are still today introducing $E$. rosea on Pacific and Indian Ocean islands.

IUCN Bulletin, 18, 7-9.

\section{Members' meetings}

\section{London meetings}

\section{Butterfly conservation}

A one-day workshop on the progress and prospects of butterfly conservation will be held on Friday 22 April 1988 at the British Museum (Natural History), Cromwell Road, London SW7 136
5BD. Organized by the Butterfly Research Association in conjunction with the FFPS, the workshop will follow closely National Butterfly Week and is part of the Natural History Museum's Spring Festival of Colour. Running from 9.30 a.m. to 5.40 p.m. it will consist of nine discussion papers in national and international aspects of butterfly conservation. Registration fee, $£ 2.00$ (including coffee and aperitifs), payable at the registration desk on the day. This will be followed from 6.15 to 9.00 p.m. by a talk, film, and wine and cheese buffet. Buffet tickets, payable in advance, are $£ 5.00$ each and are available from FFPS, 8-12 Camden High Street, London NW1 0JH, or from Campbell Smith at the BM(NH). For further information contact the organizer, Dick Vane-Wright, tel: 019389341.

\section{Regional meetings}

Friday 13 May 1988. FFPS Cambridge are holding a joint meeting with the Cambridgeshire Wildlife Trust: 'Agroforestry and Conservation'. Tickets $£ 3$ including buffet. Venue: University of Cambridge, Zoology Lecture Theatre, Downing Street at 7.30 p.m. (buffet 6.00 p.m.). Tickets from Dr A. H. Harcourt, Department of Applied Biology, Pembroke Street, Cambridge CB2 3DX.

The contact people for local group meetings are given below. Please send a stamped selfaddressed envelope with enquiries.

\section{Bristol and the West of England Group}

Ian Redmond, c/o BBC Wildlife Magazine, Broadcasting House, Whiteladies Road, Bristol BS8 2LR.

\section{Cambridge Group}

Sandy Harcourt, University of Cambridge, Department of Applied Biology, Pembroke Street, Cambridge CB2 3DX.

\section{Oxford Group}

David Macdonald, Department of Zoology, University of Oxford, South Parks Road, Oxford OX1 3PS.

\section{North-West Group}

Nick Ellerton, Chester Zoo, Caughall Road, Upton, Chester $\mathrm{CH} 2 \mathrm{LH}$.

\section{Edinburgh Group}

Jayne Williams, Edinburgh Zoo, Murrayfield, Edinburgh EH12 6TS.

Oryx Val 22 No 2, April 1988 